\title{
Sport, doping and male fertility
}

\author{
Andrea Sansone ${ }^{1}$, Massimiliano Sansone ${ }^{1}$, Diana Vaamonde ${ }^{2}$, Paolo Sgrò ${ }^{3}$, Ciro Salzano ${ }^{4}$, Francesco Romanelli ${ }^{1}$, \\ Andrea Lenzi ${ }^{1}$ and Luigi Di Luigi ${ }^{3^{*}}$
}

\begin{abstract}
It is universally accepted that lifestyle interventions are the first step towards a good overall, reproductive and sexual health. Cessation of unhealthy habits, such as tobacco, alcohol and drug use, poor nutrition and sedentary behavior, is suggested in order to preserve/improve fertility in humans. However, the possible risks of physical exercise per se or sports on male fertility are less known. Being "fit" does not only improve the sense of well-being, but also has beneficial effects on general health: in fact physical exercise is by all means a low-cost, high-efficacy method for preventing or treating several conditions, ranging from purely physical (diabetes and obesity) to psychological (depression and anxiety), highly influencing male reproduction. If male sexual and reproductive health could be positively affected by a proper physical activity, inadequate bouts of strength - both excessive intensity and duration of exercise training - are more likely to have detrimental effects. In addition, the illicit use of prohibited drugs (i.e. doping) has reached pandemic proportions, and their actions, unfortunately very often underestimated by both amateur and professional athletes, are known to disrupt at different levels and throughout various mechanisms the male hypothalamic-pituitary-gonadal axis, resulting in hypogonadism and infertility.
\end{abstract}

\section{Introduction}

Lifestyle interventions have been proven to be effective as the first step towards a good general health $[1,2]$ and even for maintaining adequate reproductive and sexual health $[3,4]$. Physical exercise is widely considered to be one of the bases of a healthy lifestyle. However, contrary to popular belief, "being fit" does not necessarily mean "being healthy". Solid evidence has suggested that adequate regular physical activity (i.e. physical exercise, sports, etc.) might have positive effects on cardiovascular, endocrine, metabolic and neurological status [5], whereas different forms of excessive and strenuous physical training often have deleterious effects on both general and reproductive health [6]. Furthermore, the widespread use of doping substances in general population and in both professional and non-professional athletes has become a worrying phenomenon in terms of health risk. Many people abuse hormones in order to provide better outcomes for their physical appearance, while - despite increasing efforts from the World Anti-Doping Agency (WADA) and from the different National Anti-Doping

\footnotetext{
* Correspondence: luigi.diluigi@uniroma4.it

${ }^{3}$ Department of Movement, Human and Health Sciences, Unit of Endocrinology, Università degli Studi di Roma "Foro Italico", Largo Lauro de Bosis 15, 00135 Rome, Italy

Full list of author information is available at the end of the article
}

Organization (NADO) - athletes are constantly looking for new drugs to improve their sports performance.

Physical exercise and sports have been observed to have the potential for affecting human's reproduction (i.e., reproduction-related sexual behavior and/or fertility), in both positive and negative ways. In males, sexual and spermatogenetic functions might be maintained or improved by adequate physical activity, whereas impairments in sexuality and/or in fertility have been observed $[3,7,8]$ following excessive training and/or drug abuse (i.e. doping) (Fig. 1).

This review aims to address how physical exercise, sports and doping might either improve or impair reproductive capacity/fertility in males.

\section{Physical exercise, sports and the male hypothalamic-pituitary-gonadal (HPG) axis}

The physiology of male reproduction is the result of fine tuning between several hormones involved in sexual function and spermatogenesis. For such purpose, the hypothalamus, pituitary and testes act together; therefore, it's common practice to describe them as a single entity, namely the hypothalamic-pituitary-gonadal (HPG) axis. After puberty, pulsatile release of gonadotropin-releasing hormone (GnRH) from hypothalamic GnRH-secreting neurons stimulates production of luteinizing hormone 


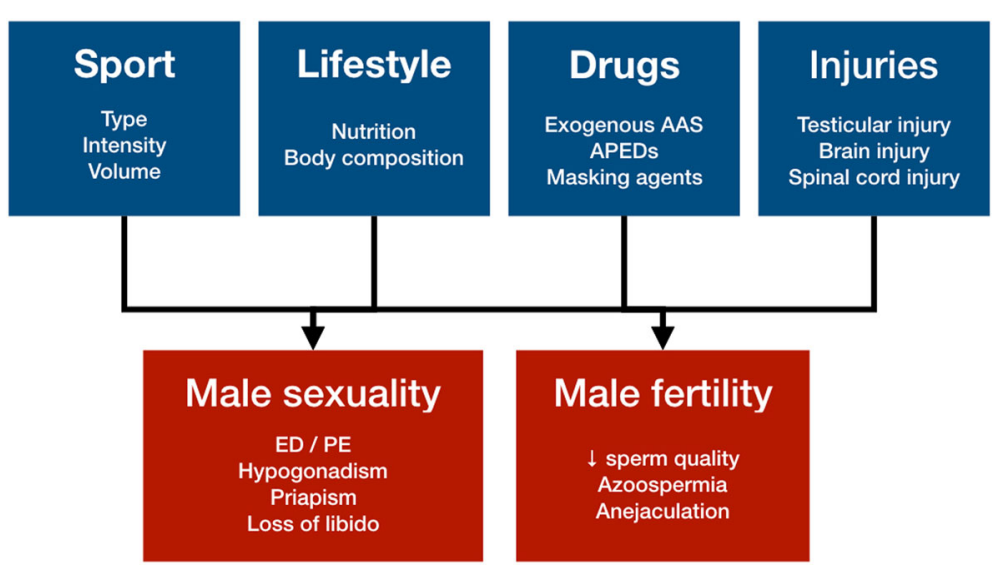

Fig. 1 Disorders of male sexual and reproductive functions in athletes. Abbreviations: AAS, androgenic anabolic steroids; APEDs, appearance and performance-enhancing drugs; $E D$, erectile dysfunction; $P E$, premature ejaculation

(LH) and follicle-stimulating hormone (FSH) from secretory cells of the anterior pituitary; in males, FSH and $\mathrm{LH}$ act on the testes, stimulating spermatogenesis and testosterone production respectively. Secretion of $\mathrm{GnRH}$ is regulated by negative feedback mechanisms involving inhibin $\mathrm{B}$, and both direct and indirect action from testosterone. Energy balance [9] dynamically regulates endogenous HPG axis, which in turn also regulates both exercise performance and success in competition [10]; unsurprisingly, both reduced androgen secretion and excessive levels of testosterone might have deleterious effects on performance as well as on general health [11].

\section{Physical exercise, sports and testosterone: The good}

Testosterone is a widely-known determinant of muscle volume, strength, function and adaptation to exercise-related stress in humans (e.g. athletes, amateurs, and so forth), whether young or older [12-14]; however, its role goes further beyond, as testosterone might influence body composition, cognitive processes, glucose and protein metabolism, erythropoiesis and reproductive function in both athletes and non-athletes [15-20] (Table 1). Its effects are patent when employing it in replacement therapy in hypogonadal subjects [18-20].

Despite lacking evidence in regards to exact mechanisms involved, acute maximal and sub-maximal physical exercise may lead to a rapid increase in serum testosterone concentration, likely resulting in better adaptation and performance in both muscle activity and functional capacity during physical exercise [21]. Physical exercise and sports competition act as a stressor, and testosterone is likely acting as a homeostatic agent, together with the whole range of hormones secreted during or shortly after physical exercise [22]. Enhanced pituitary responsiveness, improved Leydig function, reduced testosterone clearance and changes in testicular blood flow have all been investigated [23-25] as possible causes; however, no definite evidence has been obtained so far, suggesting that a combination of mechanisms is the most likely explanation. The endocrine response to exercise related stress is related to various factors (e.g. type, intensity and duration of physical activity, etc.) [21, 26-28].

\section{Physical exercise, sports and testosterone: The bad}

As previously stated, acute exercise often leads to a transient increase in testosterone levels; on the contrary, a marked decrease in testosterone levels has been suggested in athletes undergoing chronic exercise. Incorrectly executed exercise or poorly developed training programs elicit negative endocrine responses and physiological consequences [28]. The chronic exposure to excessive loads of endurance training may impair the function of the HPG axis, leading to significantly and persistently reduced basal (resting-state) free and total testosterone levels, often remaining within the physiological range [29-31], with no concurrent increase in LH levels. The resulting clinical and biochemical phenotype depicts the "exercise-hypogonadal male condition", as defined by Hackney and colleagues [29, 30]; the pathophysiology of this condition have not been fully elucidated, although pituitary GnRH resistance, increased prolactin secretion and inhibitory effects on LH secretion from ghrein and leptin have all been considered as possible "triggers". Retrospective studies have often shown a reduction of free and total testosterone concentrations in endurance-trained men, whereas prospective studies have often failed to provide definite results because of the varying features of the training period, the magnitude of training stimulus and the volume of training load employed [24].

To the present date, several authors have reported the effects of short-term and long-term intensive training: significantly decreased concentrations of total and free testosterone, as well as reduced FSH and LH secretion/ pulsatility, and increased SHBG levels have been reported 
Table 1 Physiological effects of testosterone on adaptation to physical exercise and sports performance in males. Edited from P Sgro and L Di Luigi [39]

\begin{tabular}{|c|c|}
\hline \multirow[t]{4}{*}{ Somatic Growth } & Control of growth \\
\hline & Epiphyseal cartilage closure \\
\hline & Secondary sexual characteristics \\
\hline & Somatic masculinization \\
\hline \multirow[t]{11}{*}{$\begin{array}{l}\text { Endocrine-metabolic } \\
\text { system }\end{array}$} & $\begin{array}{l}\text { Anti-cortisol effects (metabolism, steroid } \\
\text { receptor competition...) }\end{array}$ \\
\hline & Increased anaerobic glycolytic capacity \\
\hline & Increased enzymes activity in mitochondria \\
\hline & Increased phosphocreatine content \\
\hline & Increased protein anabolism \\
\hline & Increased sarco-tubular enzymes activity \\
\hline & $\begin{array}{l}\text { Inhibited stress related } \mathrm{CRH}-\mathrm{ACTH} \text {-Cortisol } \\
\text { response }\end{array}$ \\
\hline & Pro-insulin and insulin-like effects \\
\hline & Reduced protein catabolism \\
\hline & Stimulated erythropoiesis \\
\hline & Synergic effects with growth hormone \\
\hline \multirow[t]{4}{*}{ Functional capacity } & Increased aerobic and anaerobic capacity \\
\hline & Cardiovascular efficiency \\
\hline & $\begin{array}{l}\text { Increased muscle strength and explosive } \\
\text { strength }\end{array}$ \\
\hline & Increased muscle adaptation to training \\
\hline \multirow[t]{4}{*}{ Body composition } & Increased bone mineral density \\
\hline & Increased muscle mass \\
\hline & Male pattern muscle distribution \\
\hline & Reduced fat mass \\
\hline \multirow[t]{10}{*}{ Central nervous system } & Increased aggressiveness \\
\hline & Increased dominance \\
\hline & Increased inclination to command \\
\hline & Increased motivation to compete \\
\hline & Increased neuro-muscular conduction \\
\hline & Increased visual-spatial capacities \\
\hline & Reduced empathy \\
\hline & $\begin{array}{l}\text { Reduced negative reaction to external rapid } \\
\text { stimuli and/or alarms }\end{array}$ \\
\hline & Reduced perception of negative emotions \\
\hline & Reduced sense of fatigue \\
\hline \multirow{4}{*}{$\begin{array}{l}\text { Psycho-motor and } \\
\text { sports capacity }\end{array}$} & Increased aggressiveness in competition \\
\hline & Increased motivation to compete \\
\hline & Increased resistance to fatigue \\
\hline & $\begin{array}{l}\text { Increased visual-spatial orientation during } \\
\text { competition }\end{array}$ \\
\hline
\end{tabular}

following high-intensity exercise [31, 32]. More recently, cortisol and testosterone dynamics following exhaustive endurance exercise have been described in endurance-trained males, suggesting that recovery from endurance exercise sessions at ventilatory threshold might require up to $72 \mathrm{~h}$ for free testosterone to return to baseline values [33]. Previous findings in high-altitude marathon runners [34] and professional cyclists [35] provide further confirmation with regards to the effects of different kinds of exercise on testosterone secretion and profile.

Whether testosterone suppression is the result of a physiological adaptation to stress or an undesirable side effect of excessive training is a matter still open to debate. The best treatment for exercise-induced hypogonadism is to reduce exercise load; however, constant monitoring of androgen status is suggested in all athletes undergoing strenuous training in order to promptly address any issues related to testosterone deficiency.

\section{Physical exercise, sports and testosterone: The ugly}

Hormones, including testosterone, act on muscle strength, adaptation to exercise and recovery [26]: therefore, untreated male athletes with testosterone deficiency are likely to incur in specific risks for health and for their physiological adaptation and performance during exercise. Male athletes affected by untreated hypogonadism with hypo-testosteronemia (e.g. congenital hypogonadotropic hypogonadism, Klinefelter Syndrome, anorchia, and so forth) in association to worse results in terms of performance and adaptation to physical exercise and sports are more likely affected by increased risks for general health, ranging from osteoporotic fractures to cardiovascular accidents related to the combination of hypo-testosteronemia with high exercise-strain [6]. Testosterone deficiency is also, of course, an issue for all ages: hypogonadism is rarely overtly symptomatic in athletes [36] but may become a primary cause for concern in older subjects.

Given its properties, testosterone is in the WADA list of prohibited substances, and therefore athletes in need of treatment should obtain a Therapeutic Use Exemption (TUE) according to the WADA criteria by the respective NADO. To prevent misuse, both clinicians and athletes should respect the official therapeutic indications and authorized formulations/doses [37]. This procedure does not differ from others needed for other pathologies such as diabetes mellitus and adrenal insufficiency.

\section{Sports, sexual function and fertility in male athletes \\ Sexual function}

Reduced global physical exercise (i.e. sedentary behavior) is considered a risk factor for several chronic diseases and conditions, including sexual dysfunction in males $[38,39]$; therefore, it should come as no surprise that adequate physical activity is fundamental to maintain or improve sexual health $[39,40]$ and that physical activity and the level of physical fitness are both associated to 
the quality of erectile function $[39,41,42]$. Better sexual health is closely associated with improvements in sexual activity and reproductive capacity. Lifestyle modifications, including physical exercise, are in fact suggested as a first-line treatment for erectile dysfunction [43], since exercise improves bioavailability of nitric oxide and increases the number of endothelial progenitor cells, while at the same time diminishing concentrations of markers of oxidative stress [44] and expression of TNF- $\alpha$, IL-1-beta and IL-6, therefore improving endothelial function [45] and consequently reducing the risk for erectile dysfunction [46]. Two recent meta-analysis studies have proven the benefits of moderate, or moderate-to-vigorous healthy physical activity on erectile function, in both short-term and long-term interventions as well as in trials evaluating physical activity and exercise alone or in addition to usual care [47, 48]; however, suggesting that all kinds of physical exercise improve sexual health is misleading, as clearly proven in female athletes suffering from the "female athlete triad" - a syndrome featuring low energy availability, menstrual dysfunction, and low bone mineral density, frequently observed in a variety of sports [49]. Some analogies between female and male athletes have been described in regards to bone health and nutritional deficiencies, but there are also similarities concerning sexual dysfunctions in both sexes [50]. Male athletes suffering from exercise-induced hypogonadism are more likely to develop erectile dysfunction and ejaculatory disorders, as both conditions are also closely associated with reduced testosterone [51, 52]. Reduced sexual drive is among the classical symptoms of androgen deficiency [53], and testosterone supplementation is likely to improve sexual function in hypogonadal subjects [54]; however, a reduced exercise load is the suggested treatment in athletes suffering from exercise-induced hypogonadism [29], although unrealistic for athletes whose ultimate goal is to compete and win.

Premature ejaculation (PE) is the most common male sexual dysfunction, with an estimated prevalence ranging from 8 to $30 \%$ up to $22-38 \%$ in all age groups [52]. The pathogenesis of PE is complex, possibly involving psychological disturbances, alterations in hormonal status and lower urinary tract infections; however, as already mentioned in regards to erectile disorders, lifestyles seem to heavily influence orgasmic function. A negative association has been recently described between physical activity and PE, suggesting that PE is more likely to occur in patients reporting lower levels of physical exercise [55]: this preliminary finding, however, deserves attention since the significance of the association did not change despite correction for age, erectile dysfunction, alcohol use and body mass index.

\section{Fertility}

Physically active subjects are more likely to have better sexual health, and are therefore more likely to have sexual activity [39]; however, despite the "need" to have sex in order to conceive, the issue of male fertility is a separate entity, requiring a completely different approach. Male fertility is remarkably affected by a variety of lifestyle factors, exerting either positive or negative effects on spermatogenesis [56]. Smoking, alcohol use, sedentary behavior are known risk factors for male infertility; however, how physical exercise may relate to male infertility is still unclear as contradictory results in different studies have been found to date [56, 57].

Different kinds of physical activity characterized by a different exercise load, might have different effects on sperm parameters [57]. The positive effects of an active lifestyle on spermatogenesis have been confirmed by comparing sperm parameters of physically active and sedentary men [58]; higher levels (in the normal range) of FSH, LH and testosterone have been described in physically active subjects compared to sedentary subjects. More recent reports have concluded that moderate training is associated with improvements in sperm DNA integrity and semen quality and with reduced expression of seminal markers of inflammation and oxidative stress [59-63]. However, once again, deleterious consequences for spermatogenesis have been repeatedly described following intensive exercise loads [31, 64, 65]; worse morphology and concentration have been described in triathletes compared to physically active subjects and water polo players, therefore suggesting that more strenuous feats might actually prove harmful to spermatogenesis and sperm DNA integrity, and even seminal antioxidant capacity $[7,57,58,66]$. In some of the early years De Souza and colleagues already hypothesized a volume threshold to start observing reproductive alterations [65], besides the other findings already described both an increase in reactive oxygen species (ROS) production and a decrease in ROS scavengers have been described after 16 weeks of intensive cycling training in humans [64] as well as in animal models reflecting apoptotic events on the spermatogenic lineage $[67,68]$. Cycling more than $5 \mathrm{~h}$ per week has been associated with a decline in both sperm concentration and motility [69].

Evidence would once again seem to suggest that moderate, healthy exercise is the key for a better overall health, whereas excessive loads of endurance training are more likely to induce worse outcomes, also in terms of fertility [8].

Besides volume and intensity, several factors might affect male fertility in athletes. Physical exercise is often suggested as a means for weight loss: in regards to male fertility, this has proven useful in improving sperm parameters [70]. However, adequate physical activity is 
only moderately useful for assisted reproduction techniques, as improvements in sperm parameters do not always mirror clinical outcomes (i.e. clinical pregnancy or live birth rates) [71]. Furthermore, as previously stated, excessive training might result in worse sperm parameters $[69,71]$, possibly negatively affecting the chances of successful treatment (Table 2). It should be taken into account that professional athletes perform higher absolute volumes of training at top-end intensity compared with amateur athletes; nevertheless, the same relative intensity elicits less physical stress on professional athletes compared to amateur ones [72, 73]. Training intensity should be considered different according to the athlete's status (Tables 3, 4, 5). Furthermore, professional athletes may be more prone to evaluate training intensity according to parameters different from heart rate, which is affected by many variables (i.e stimulants, diet, hydration status, sports, temperature).

\section{Potential mechanisms involved in negative effects of physical activity on male fertility}

Despite a solid body of evidence proving that excessive physical exercise might negatively affect male fertility, there is little knowledge concerning the potential mechanisms involved in the decrease of sperm quality. Exercise-induced hypogonadism is likely to occur in a minority of athletes; therefore, several hypotheses have been postulated in order to correctly address this issue. Any increase in scrotal temperature is likely to impair spermatogenesis by induction of germ cell death: mechanisms include autophagy, DNA damage and apoptosis [74]. Everyday clothing is supposed to have an effect on spermatogenesis [75]: tight undertrousers provide significantly more heat to testes compared to loose-fitting ones, a phenomenon seemingly attenuated by walking because of perigenital air circulation [76]. Whether more intense physical activity is associated with increased scrotal temperature is still a matter for debate [77, 78]. Exercise-induced hypoxia has been described in exercise training, as well as in aging [25]; testicular dysfunction observed in high-altitude exercise is possibly associated with reduced oxygen availability, and might impair male fertility resulting in reduced sperm concentration [79]. Similar reports have also addressed the effects of deep saturation dive on male fertility: negative effects on sperm motility and concentration were observed shortly after the dive and remained consistent up to 3 months later, suggesting that hyperbaric conditions are likely to impair spermatogenesis [80]. Pudendal nerve compression, repeated trauma on the pelvic floor and other morpho-functional alterations commonly observed in cycling have been considered possible causes of male infertility as well [81].

\section{Morpho-functional alterations and reproduction in male athletes}

Some kinds of sports have been closely associated with male HPG morpho-functional alterations ultimately resulting in worse sexual function and/or reduced fertility. Brain and spinal cord injuries, as well as local trauma, are often cited as the most prevalent sports-related morpho-functional alterations possibly leading to erectile dysfunction and male infertility.

Traumatic brain injuries, as observed in football players [82] and in kickboxers [83], may lead to long-term impairment of pituitary secretion [84], most often acutely presenting as isolated GH deficiency [85] but possibly involving multiple axes during follow-up [86]. Causes of hypopituitarism following concussion are still unknown: there are a few hypotheses in these regards, suggesting a role of hemorrhage, edema, autoimmunity [87] or inflammatory and hypoxic state [85].

Pudendal nerve compression due to cycling is another complex, interesting phenomenon often resulting in urogenital complications [81]. Either because of mechanical pressure, transient hypoxemia, or arterial insufficiency, ischemic neuropathy is likely to occur in cyclists; this might provide an explanation to the increased odds ratio for erectile dysfunction in people cycling more than $3 \mathrm{~h}$ per week [88]. Cycling has also been associated with chronic prostatitis, a condition affecting both sexual and reproductive health $[78,81]$. High-flow priapism is similarly more prevalent in cyclists: exercise-induced vascular trauma resulting in arterial-venous shunt is the most common etiology for this condition [81].

Increased abdominal pressure supposedly aggravates the development of varicocele in males. Rigano et al. reported significantly increased prevalence of higher grades of varicocele among athletes compared to non-athletes, with more severe forms affecting those training more than $6 \mathrm{~h}$ per week [89]. Physical activity might also be an aggravating factor for athletes with varicocele: despite there being no statistically significant difference in sperm parameters between healthy athletes and controls, varicocele seems to be associated with worse outcomes in athletes compared to non-athletes in terms of sperm morphology [90]. All athletes with varicocele should be clinically monitored, and treatment should be proposed if needed in order to preserve fertility and guarantee safe sport participation. More recently, Zampieri and Dall'Agnola suggested that sports practice might facilitate progression to clinical varicocele only in subjects affected by subclinical forms of varicocele [91].

Sports-related spinal cord injuries (SCIs) are uncommon outcomes of physical activity, although their rate is remarkably higher in some kinds of sports, such as rugby, diving and horseback riding [92]. The incidence of SCIs has dramatically reduced in the last decades; 
Table 2 Effects of sports and physical activity on human semen parameters: studies reporting effects of physical activity and sports on male fertility

\begin{tabular}{|c|c|c|}
\hline Reference & Population studied & Results \\
\hline $\begin{array}{l}\text { Vaamonde } \\
\text { et al. [7] }\end{array}$ & $\begin{array}{l}12 \text { high-level triathletes after 2-weeks period of tapering } \\
\text { (lowered training volume) }\end{array}$ & $\begin{array}{l}\uparrow \text { DNA fragmentation } \\
\uparrow \text { round cells }\end{array}$ \\
\hline \multirow{3}{*}{$\begin{array}{l}\text { Vaamonde } \\
\text { et al. [57] }\end{array}$} & 16 physically active subjects & \multirow{3}{*}{$\begin{array}{l}\text { Following more strenuous exercise: } \\
\downarrow \text { sperm count, } \downarrow \text { morphology }\end{array}$} \\
\hline & 14 water polo players & \\
\hline & 15 "Ironman" triathletes & \\
\hline $\begin{array}{l}\text { Vaamonde } \\
\text { et al. [66] }\end{array}$ & Case report - triathlete & $\begin{array}{l}\uparrow \text { DNA fragmentation } \\
\uparrow \text { round cells } \\
\downarrow \text { total antioxidant capacity }\end{array}$ \\
\hline \multirow{2}{*}{$\begin{array}{l}\text { Vaamonde } \\
\text { et al. [58] }\end{array}$} & 16 physically active subjects & \multirow[t]{2}{*}{$\uparrow$ sperm count and morphology, $\uparrow \mathrm{FSH}, \mathrm{LH}$ and $\mathrm{T}$ in physically active men } \\
\hline & 15 sedentary men & \\
\hline $\begin{array}{l}\text { Maleki } \\
\text { et al. [59] }\end{array}$ & $\begin{array}{l}280 \text { men, randomized to moderate-intensity continuous } \\
\text { training (MICT), high-intensity continuous training (HICT), } \\
\text { high-intensity interval training (HIIT) or no-exercise }\end{array}$ & $\begin{array}{l}\uparrow \text { semen quality and DNA integrity, } \downarrow \text { markers of inflammation and oxidative } \\
\text { stress in all exercise groups compared to no-exercise; best results for MICT } \\
\text { compared to HICT and HIIT }\end{array}$ \\
\hline $\begin{array}{l}\text { Maleki } \\
\text { et al. [60] }\end{array}$ & $\begin{array}{l}\text { Semen samples from } 56 \text { elite athletes, } 52 \text { recreationally } \\
\text { active men and } 53 \text { non-active men }\end{array}$ & $\begin{array}{l}\uparrow S O D \text {, catalase and total antioxidant capacity and } \downarrow \text { 8-Isoprostane, ROS and } \\
\text { MDA in recreationally active men; } \\
\downarrow \text { SOD, catalase and total antioxidant capacity and } \uparrow \text { 8-Isoprostane, ROS and } \\
\text { MDA in elite athletes }\end{array}$ \\
\hline $\begin{array}{l}\text { Rosety } \\
\text { et al. [62] }\end{array}$ & $\begin{array}{l}90 \text { obese adults, randomized to either intervention group } \\
(45 \text { men, } 16 \text {-week aerobic training - treadmill) and control } \\
\text { group ( } 45 \text { men). }\end{array}$ & $\begin{array}{l}\uparrow \text { testosterone, sperm concentration, motility and morphology in } \\
\text { intervention group }\end{array}$ \\
\hline $\begin{array}{l}\text { Maleki } \\
\text { et al. [63] }\end{array}$ & $\begin{array}{l}433 \text { Infertile men, randomly assigned to high-intensity } \\
\text { exercise }(n=218) \text { or control }(n=215) \text { groups }\end{array}$ & $\begin{array}{l}\downarrow \| L-6 \text {, TNF-a, ROS, MDA, and } \uparrow \text { SOD, catalase, and total antioxidant capacity } \\
\text { in high-exercise group }\end{array}$ \\
\hline $\begin{array}{l}\text { Maleki } \\
\text { et al. [64] }\end{array}$ & $\begin{array}{l}24 \text { non-professional male cyclists, undergoing } 16 \text { weeks } \\
\text { of intensive training }\end{array}$ & $\begin{array}{l}\uparrow \text { sperm ROS and MDA and } \downarrow S O D \text {, catalase and total antioxidant capacity, } \\
\text { persisting up to } 30 \text { days post-exercise }\end{array}$ \\
\hline $\begin{array}{l}\text { Wise et al. } \\
\text { [69] }\end{array}$ & 4565 semen samples from 2261 men undergoing ART & $\downarrow$ sperm concentration and motility in men bicycling $\geq 5 \mathrm{~h} / \mathrm{wk}$ \\
\hline $\begin{array}{l}\text { Jozkow } \\
\text { et al. [8] }\end{array}$ & $\begin{array}{l}177 \text { young "lean, educated, and physically active" healthy } \\
\text { males }\end{array}$ & $\uparrow \%$ immotile sperm in physical exercise (3rd - 4th quartile) \\
\hline Maleki [61] & $\begin{array}{l}419 \text { sedentary infertile men, randomized to either } \\
\text { exercise }(n=210) \text { or no exercise }(n=209)\end{array}$ & $\begin{array}{l}\downarrow \| \mathrm{L}-1 \mathrm{~b}, \mathrm{IL}-6, \mathrm{IL}-8, \mathrm{TNF}-\mathrm{a}, \mathrm{ROS}, \mathrm{MDA}, 8 \text {-isoprostane and } \uparrow \text { sperm integrity, } \\
\text { SOD, catalase, total antioxidant capacity and pregnancy rate in exercise } \\
\text { group }\end{array}$ \\
\hline
\end{tabular}

however, the devastating effect on the involved athletes' quality of life has often rekindled media attention in these regards. Spinal trauma may result in different clinical syndromes based on the location of the lesion and on subsequent secondary events, such as hemorrhage and edema [93]. SCIs most frequently occur in young,

Table 3 Levels of risk based on physical activity volume and intensity

\begin{tabular}{ll}
\hline Volume (hours/week) and intensity & Level of Risk \\
\hline $\begin{array}{l}\text { moderate and high intensity [137] } \\
\text { 20-30 h training or racing/weeks including }\end{array}$ & Very high risk \\
moderate and high intensity [138] & High risk \\
$\begin{array}{l}\text { 10-20 h training or racing/weeks including } \\
\text { moderate and high intensity [57, 139] }\end{array}$ & Medium risk \\
$\begin{array}{l}\text { 5-15 h training or racing/weeks not including } \\
\text { moderate and high intensity [140-142] }\end{array}$ & Low risk \\
Less than 5 h training or racing/weeks not & Very low risk \\
including moderate and high intensity [143, 144] & \\
\hline
\end{tabular}

male athletes as compared to female athletes [94] and impair the ability to obtain erection and to achieve ejaculation. Parasympathetic fibers originating from S2-S4 and entering the corpora cavernosa are needed for erectile function; patients with SCIs often lose psychogenic erections but may maintain reflexogenic erections, although this rarely allows for intercourse [94]. Both sympathetic fibers from segments T10-L2 and somatic fibers from segments $\mathrm{S} 2-\mathrm{S} 4$ are involved in the ejaculatory reflex; more in detail, fibers from the segments T11-L2 transmit a signal via the hypogastric nerve plexus ultimately resulting in emission [95]. Semen samples might still be collected, either through penile vibratory stimulation or via electro-ejaculation [96], and might often represent the only chance for fatherhood for these subjects.

Last, but not least, the issue of pelvic trauma deserves attention: in fact, more than half of testicular injuries occur during physical activity, most often as a result of blunt force trauma. In the most severe circumstances 
Table 4 Training Intensity for amateur athletes [143, 145-147]

\begin{tabular}{llll}
\hline Intensity & $\begin{array}{l}\text { \% Heart rate Reserve (HRR) or \% } \\
\text { oxygen uptake reserve (VO2R) }\end{array}$ & $\begin{array}{l}\text { \% Heart rate } \\
\text { (HR) max }\end{array}$ & $\begin{array}{l}\text { \% maximum oxygen } \\
\text { uptake (VO2max) }\end{array}$ \\
\hline Very low & $<30$ & $<57$ & $<37$ \\
Low & $30-39$ & $57-63$ & $37-45$ \\
Moderate & $40-59$ & $64-76$ & $46-63$ \\
High & $60-89$ & $77-95$ & $64-90$ \\
Very High (Elite training) & $>90$ & $>96$ & $>91$ \\
\hline
\end{tabular}

the resulting testicular damage might lead to primary hypogonadism; furthermore, the creation of anti-sperm autoantibodies might also affect male fertility [97]. Testicular torsion usually presents without any previous traumatic injuries to the scrotum, with only $4-8 \%$ of cases resulting from trauma [98]; however, some kinds of physical activity, most notably cycling, are linked to an increased risk of testicular torsion [81]. Potential mechanisms resulting in testicular torsion are the repeated up-and-down movements of the legs, contraction of the cremasteric muscles and exaggerated cremasteric reflex [81]. Blunt force trauma applied to the perineum might also result in penile injuries, although much less commonly than testicular injuries [99].

\section{Doping, sexual function and fertility in male athletes}

The "doping epidemics" has crossed the boundaries of elite sports, and now appeals to a wide audience of subjects from medal-winning athletes aiming to excel in competitions, to amateurs aiming to improve their looks without effort, "appearance and performance-enhancing drugs" (APEDs) use is widespread and seemingly increasing in recent years $[100,101]$. The WADA has been actively involved in doping control, and several athletes have been sanctioned for doping use; however, the issue with APEDs lies not only in the effects on performance, but also in the possible - and often misjudged - side effects associated with their use (Table 6). Furthermore, many supplements have hormone-related effects despite being advertised as "natural compounds" [102], or might affect the endocrine milieu through indirect pathways [103], possibly by tampering with the "biological clock" and therefore acting as endocrine disruptors.

\section{Testosterone and androgenic anabolic steroids}

It is widely accepted that administration of exogenous testosterone and/or of other androgenic anabolic steroids (AAS) exerts a suppressive effect on the HPG axis [104]. Sexual and reproductive health are often impaired as a result of AAS-induced hypogonadism $[39,104]$. Erectile dysfunction might be the first symptom of prolonged AAS abuse for subjects who are not interested in their fertility: clinicians should therefore pay attention to signs of AAS-induced hypogonadism during clinical assessment. Erectile dysfunction often occurs during the "post-cycle" period in abusers, when serum testosterone reaches its minimum, and is often associated with use of some AAS, most notably nandrolone [105].

Up to $2 \%$ of cases of male infertility can be explained by AAS abuse, whereas the vast majority of behavior-related infertility in female athletes is the result of excessive exercise [106]. Unsurprisingly, low levels of FSH are closely associated with reduced sperm count; clinically, prolonged abuse of AAS is likely to induce testicular shrinkage because of tubular atrophy, due to HPG axis suppression. Studies in animal models have also suggested possible effects of AAS on male germ line apoptosis, as observed via TUNEL, caspase- 3 assay and transmission electron microscopy [107, 108]. Compared to erectile function, reproductive function is less likely to be permanently impaired by AAS: for most people spontaneous resolution of AAS-induced oligozoospermia and azoospermia has been observed in less than a year after discontinuation of APEDs [109].

AAS suppress intra-testicular testosterone production by inhibition of the HPG axis [110]: therefore, selective estrogen receptor modulators (SERMs) and gonadotropins have been used in order to quicken recovery following AAS cessation $[111,112]$, but individual response to

Table 5 Training intensity for elite athletes [73, 148, 149]

\begin{tabular}{|c|c|c|c|c|c|}
\hline Intensity & $\begin{array}{l}\% \text { Heart rate } \\
\text { (HR) max }\end{array}$ & $\begin{array}{l}\% \text { maximum oxygen } \\
\text { uptake }\left(\mathrm{VO}_{2} \text { max }\right)\end{array}$ & Ventilatory Threshold (VT) & $\begin{array}{l}\text { Blood Lactate } \\
\text { Levels (mM) }\end{array}$ & Lactate Threshold (LT) \\
\hline Very low & $54-73$ & $50-65$ & $<\mathrm{VT} 1$ & $<1.2$ & $<\mathrm{LT} 1$ \\
\hline Low & $74-83$ & $66-80$ & & $1.3-2.0$ & \\
\hline Moderate & $84-88$ & $81-87$ & VT $1-V T 2$ & $2.1-3.6$ & LT 1 - LT 2 \\
\hline High & 89-93 & 88-93 & & $4.3-5.7$ & \\
\hline Very High (Elite training) & $>94$ & $94-100$ & $>\mathrm{VT} 2$ & $>5.8$ & $>$ LT 2 \\
\hline
\end{tabular}


Table 6 Doping agents and their effects on male sexual and reproductive health

\begin{tabular}{|c|c|c|c|c|c|}
\hline \multirow[t]{2}{*}{ Substance(s) } & \multirow[t]{2}{*}{ Used: } & \multicolumn{4}{|c|}{ Effects on... } \\
\hline & & $\begin{array}{l}\text { Sexual } \\
\text { desire }\end{array}$ & $\begin{array}{l}\text { Erectile } \\
\text { function }\end{array}$ & Ejaculatory function & $\begin{array}{l}\text { Male } \\
\text { fertility }\end{array}$ \\
\hline $\begin{array}{l}\text { Androgenic anabolic } \\
\text { steroids }\end{array}$ & $\begin{array}{l}\text { - for ergogenic and anabolic actions } \\
\text { - for effects on CNS ( } \uparrow \text { aggressiveness, } \uparrow \\
\text { competitiveness...) }\end{array}$ & $\uparrow$ or $\downarrow$ & $\downarrow$ & $\downarrow$ (delayed ejaculation, anejaculation) & $\downarrow$ \\
\hline$\beta$-blockers & $\begin{array}{l}\text { - to } \downarrow \text { anxiety } \\
\text { - to } \downarrow \text { tremors } \\
\text { - to } \downarrow \text { heart rate }\end{array}$ & & $\downarrow$ & $\downarrow$ (delayed ejaculation, anejaculation) & \\
\hline Diuretics & $\begin{array}{l}\ldots \text { as masking agents } \\
\ldots \text { for bodybuilding }\end{array}$ & & $\downarrow$ & $\downarrow$ (delayed ejaculation, anejaculation) & \\
\hline $\begin{array}{l}\text { Amphetamine, } \\
\text { stimulants }\end{array}$ & $\begin{array}{l}\ldots \text { for effects on CNS ( } \uparrow \text { aggressiveness, } \uparrow \\
\text { competitiveness...) } \\
\ldots \text { for (unproven) ergogenic properties }\end{array}$ & $\uparrow$ or $\downarrow$ & $\downarrow$ & $\begin{array}{l}\uparrow \text { or } \downarrow \text { (premature delayed or ejaculation, } \\
\text { anejaculation) }\end{array}$ & $\downarrow$ \\
\hline
\end{tabular}

treatment is highly variable and therefore difficult to assess. Several factors complicate the assessment of the effects of AAS on reproductive and sexual function, such as multi-drug regimens "stacking" several molecules [113] and depot effects [114]: for the same reasons, recovery may take a long time, even $12-24$ months following prompt discontinuation of APEDs. More severe effects might occur in patients abusing AAS in puberty, as changes in the HPG axis in this time frame might lead to long-lasting damage on sexual health and development $[115,116]$. In these regards, several treatments have been proposed for AAS-induced hypogonadism: SERMs such as clomiphene citrate $25 \mathrm{mg}$ on alternate days have been successfully used for management of low testosterone, possibly after a 4-week tapered course of testosterone replacement therapy for more severe cases [105]. Should testosterone levels fail to rise despite treatment, primary testicular failure should be suspected and recovery is limited. Recent reports on hCG-based combined treatment seem to suggest that the vast majority of cases of testosterone-related azoospermia or oligozoospermia would benefit from treatment, with no significant difference in regards to supplemental therapies [117]. Another issue lies in the frequent use of multi-drug regimens [113]: athletes often "mix" AAS and other substances, most notably hCG, in order to reduce the suppression on the HPG axis or in hopes of synergies between treatments. Little evidence has been published in these regards, but reports suggest that conjoined administration of hCG and AAS impairs fertility [118], similarly to what has been described in AAS-only abusers. In addition, we highlight that it is not known if and how the large use and abuse of not prohibited substances (e.g. supplements, ergogenic aids and drugs) in athletes (i.e. not considered doping), often associated to the assumption of prohibited substances (i.e. doping), could influence the reproductive axis [103, 119-121].

A question largely left unanswered is whether administration of AAS during puberty is likely to impair spermatogenesis: reports from over-tall boys treated with high doses of testosterone seem to suggest that recovery time is not different from non-treated subjects [104], but evidence is inconsistent and caution is therefore advised.

\section{Non-hormonal drugs used for performance and appearance enhancement}

Despite being significantly less common than AAS, several substances have been used in different sports in order to enhance performance; however, negative effects of these drugs have been reported concerning sexual and reproductive function. Beta-blockers, often used in order to reduce anxiety and tremors in precision sports, are likely to worsen erectile function [122]; furthermore, in vitro studies have reported inhibitory effects of beta-blockers on smooth muscle in reproductive tracts, possibly resulting in delayed ejaculation or, in the most severe cases, anejaculation [123]. In regards to cardiovascular treatments, diuretics, most notably thiazides, might impair erectile function [124]: these drugs are sometimes used by athletes in order as masking agents for concomitant treatments [125], but use of these drugs by bodybuilders aiming to improve their physical appearance is an increasingly worrying phenomenon [126] and their possible side effects might be amplified by coexisting eating disorders [127]. Amphetamines and stimulants - including some over the counter treatments, such as pseudoephedrine [128] - are used for their effects on the central nervous system [129]: by enhancing reflexes, increasing aggressiveness and (possibly) having ergogenic effects, these drugs are ideal candidates as doping agents in sports involving short bursts of speed or strength [130]. Among their side effects, these substances might both enhance or worsen erectile function, sexual drive and ejaculatory latency [131]; in animal models, testicular damage resulting in impaired fertility has been described in rats treated with amphetamine, suggesting a negative effect on spermatogenesis as well [132]. Carnitine, a compound with reported antioxidant 
properties, is often used as an APED; while some effects on sperm parameters have been reported in several in vivo studies using less than $3 \mathrm{~g} /$ day, there is no evidence on the effects of high carnitine intake on male fertility [133]. Similarly, several other compounds are often used for performance enhancing purposes, such as amino acids and soy or milk proteins. Some authors have reported negative effects of soy proteins on male fertility [134], although other studies have suggested otherwise [135]; likewise, creatine and other compounds commonly used by athletes, have not been adequately investigated in regards to their possible effects on spermatogenesis and fertility [136].

\section{Conclusions}

Physical exercise and sports may exert both beneficial and deleterious effects on male sexual and reproductive health, depending on the imposed demands of exercise mode itself. Physical exercise is usually a valid tool in prevention of non-communicable diseases, such as heart disease and obesity, and is therefore generally suggested to all patients as a first-line therapy for a variety of conditions. However, while adequate physical exercise is key to a healthy lifestyle, excessive intensity or volume of training often lead to negative, undesired effects, such as infertility and sexual dysfunction. Furthermore, physical injuries resulting from sports, such as head trauma or spinal cord injuries, might have negative effects on general health, as well as sexual function. In order to identify whether reduced loads of exercise should be suggested in order to reduce the burden on male sexual and reproductive functions, assessment by a trained specialist is recommended for all athletes, whether professional or amateurs. Nevertheless, one must be aware that, especially in the case of professional athletes, it may be unrealistic to modify their training loads. Moreover, doping has a negative impact on male reproductive function, not only on semen quality but having an effect on the endocrine regulatory axis as well as the testes and accessory ducts, and sexual performance as evidenced in both human and animal model studies. This effect has been observed to revert in approximately 1 year upon cessation of substance abuse, except in extreme cases. Some studies assessing the impact of AAS abuse reflect that athletes may later on regret taking them. Therefore, it seems logical that clear and ample information to athletes about possible risks of exercise and AAS abuse is a must.

\section{Acknowledgements}

The authors would like to thank Rosario Pivonello and Cristina de Angelis for their role as Guest Editors.

Funding

No funding was requested for this review.

\section{Availability of data and materials}

Literature research results are available from the authors on reasonable request.

\section{Authors' contributions}

LDL conceived the idea. AS and MS were involved in literature collection. All authors independently and critically reviewed the selected manuscripts. AS, MS and DV were involved in drafting the early manuscript, which was then expanded and improved by all authors. All authors reviewed and approved the completed manuscript.

\section{Ethics approval and consent to participate}

Not applicable.

\section{Consent for publication}

Not applicable.

\section{Competing interests}

The authors declare that they have no competing interests.

\section{Publisher's Note}

Springer Nature remains neutral with regard to jurisdictional claims in published maps and institutional affiliations.

\section{Author details}

${ }^{1}$ Department of Experimental Medicine, Section of Medical Pathophysiology, Food Science and Endocrinology, Sapienza - University of Rome, Viale Regina Elena 324, 00161 Rome, Italy. ${ }^{2}$ Morphological Sciences Department, School of Medicine, Universidad de Córdoba, Cordoba, Spain. ${ }^{3}$ Department of Movement, Human and Health Sciences, Unit of Endocrinology, Università degli Studi di Roma "Foro Italico", Largo Lauro de Bosis 15, 00135 Rome, Italy. ${ }^{4}$ Dipartimento di Medicina Clinica e Chirurgia, Sezione di Endocrinologia, Università "Federico II" di Napoli, Naples, Italy.

Received: 1 October 2017 Accepted: 24 October 2018

Published online: 12 November 2018

References

1. Sun Y, You W, Almeida F, Estabrooks P, Davy B. The effectiveness and cost of lifestyle interventions including nutrition education for diabetes prevention: a systematic review and Meta-analysis. J Acad Nutr Diet. 2017; 117(3):404-21 e436.

2. Eijsvogels TM, Molossi S, Lee DC, Emery MS, Thompson PD. Exercise at the extremes: the amount of exercise to reduce cardiovascular events. J Am Coll Cardiol. 2016;67(3):316-29.

3. Zeinab H, Zohreh S, Samadaee Gelehkolaee K. Lifestyle and outcomes of assisted reproductive techniques: a narrative review. Glob J Health Sci. 2015;7(5):11-22.

4. Rossi BV, Abusief M, Missmer SA. Modifiable risk factors and infertility: what are the connections? Am J Lifestyle Med. 2014;10(4):220-31.

5. Jonas S, Phillips EM. ACSM's exercise is medicine TM: a Clinician's guide to exercise prescription. Philadelphia: Wolters Kluwer Health, Lippincott Williams \& Wilkins; 2009

6. Di Luigi L, Romanelli F, Sgro P, Lenzi A. Andrological aspects of physical exercise and sport medicine. Endocrine. 2012;42(2):278-84.

7. Vaamonde D, Algar-Santacruz C, Abbasi A, Garcia-Manso JM. Sperm DNA fragmentation as a result of ultra-endurance exercise training in male athletes. Andrologia. 2018;50(1)

8. Jozkow P, Medras M, Lwow F, Zagrodna A, Slowinska-Lisowska M. Associations between physical activity and semen quality in young healthy men. Fertil Steril. 2017;107(2):373-8 e372.

9. Schneider JE. Energy balance and reproduction. Physiol Behav. 2004; 81(2):289-317.

10. Wood RI, Stanton SJ. Testosterone and sport: current perspectives. Horm Behav. 2012;61(1):147-55.

11. Hooper DR, Kraemer WJ, Saenz C, Schill KE, Focht BC, Volek JS, Maresh CM. The presence of symptoms of testosterone deficiency in the exercisehypogonadal male condition and the role of nutrition. Eur J Appl Physiol. 2017;117(7):1349-57.

12. Hackney AC. Stress and the neuroendocrine system: the role of exercise as a stressor and modifier of stress. Expert Rev Endocrinol Metab. 2006; 1(6):783-92. 
13. Maggio M, Ceda GP, Lauretani F, Bandinelli S, Metter EJ, Guralnik JM, Basaria S, Cattabiani C, Luci M, Dall'Aglio E, et al. Gonadal status and physical performance in older men. Aging Male. 2011;14(1):42-7.

14. Baldari C, Di Luigi L, Emerenziani GP, Gallotta MC, Sgro P, Guidetti L. Is explosive performance influenced by androgen concentrations in young male soccer players? Br J Sports Med. 2009;43(3):191-4

15. Bhasin S, Woodhouse L, Casaburi R, Singh AB, Bhasin D, Berman N, Chen X, Yarasheski KE, Magliano L, Dzekov C, et al. Testosterone dose-response relationships in healthy young men. Am J Physiol Endocrinol Metab. 2001; 281(6):E1172-81.

16. Crewther BT, Cook C, Cardinale M, Weatherby RP, Lowe T. Two emerging concepts for elite athletes: the short-term effects of testosterone and cortisol on the neuromuscular system and the dose-response training role of these endogenous hormones. Sports Med (Auckland, NZ). 2011;41(2):103-23.

17. Di Luigi L, Baldari C, Gallotta MC, Perroni F, Romanelli F, Lenzi A, Guidetti L. Salivary steroids at rest and after a training load in young male athletes: relationship with chronological age and pubertal development. Int J Sports Med. 2006;27(9):709-17.

18. Isidori AM, Giannetta E, Greco EA, Gianfrilli D, Bonifacio V, Isidori A, Lenzi A, Fabbri A. Effects of testosterone on body composition, bone metabolism and serum lipid profile in middle-aged men: a meta-analysis. Clin Endocrinol. 2005;63(3):280-93.

19. Nieschlag E, Behre HM, Bouchard P, Corrales JJ, Jones TH, Stalla GK, Webb SM, Wu FC. Testosterone replacement therapy: current trends and future directions. Hum Reprod Update. 2004;10(5):409-19.

20. Zitzmann M, Nieschlag E. Effects of androgen replacement on metabolism and physical performances in male hypogonadism. J Endocrinol Invest. 2003;26(9):886-92.

21. Sgro P, Romanelli F, Felici F, Sansone M, Bianchini S, Buzzachera CF, Baldari C, Guidetti L, Pigozzi F, Lenzi A, et al. Testosterone responses to standardized short-term sub-maximal and maximal endurance exercises: issues on the dynamic adaptive role of the hypothalamic-pituitary-testicular axis. J Endocrinol Invest. 2014;37(1):13-24.

22. Viru M, Hackney AC, Karelson K, Janson T, Kuus M, Viru A. Competition effects on physiological responses to exercise: performance, cardiorespiratory and hormonal factors. Acta Physiol Hung. 2010:97(1):22-30.

23. di Luigi L, Guidetti L, Pigozzi F, Baldari C, Casini A, Nordio M, Romanelli F. Acute amino acids supplementation enhances pituitary responsiveness in athletes. Med Sci Sports Exerc. 1999;31(12):1748-54

24. Kraemer WJ, Ratamess NA. Hormonal responses and adaptations to resistance exercise and training. Sports Med (Auckland, NZ). 2005;35(4):339-61.

25. Dominguez JM 2nd, Davis RT 3rd, McCullough DJ, Stabley JN, Behnke BJ. Aging and exercise training reduce testes microvascular PO2 and alter vasoconstrictor responsiveness in testicular arterioles. Am J Physiol Regul Integr Comp Physiol. 2011;301(3):R801-10.

26. Di Luigi L, Guidetti L, Baldari C, Romanelli F. Heredity and pituitary response to exercise-related stress in trained men. Int J Sports Med. 2003;24(8):551-8.

27. Minetto MA, Paccotti P, Borrione P, Massazza G, Ventura M, Termine A, Di Luigi L, Pigozzi F, Angeli A. Effects of the training status on the hormonal response and recovery from high-intensity isokinetic exercise: comparison between endurance-trained athletes and sedentary subjects. J Sports Med Phys Fitness. 2006;46(3):494-500.

28. Hackney AC, Lane AR. Exercise and the regulation of endocrine hormones. Prog Mol Biol Transl Sci. 2015;135:293-311.

29. Hackney AC. Effects of endurance exercise on the reproductive system of men: the "exercise-hypogonadal male condition". J Endocrinol Invest. 2008; 31(10):932-8.

30. Hackney AC, Moore AW, Brownlee KK. Testosterone and endurance exercise: development of the "exercise-hypogonadal male condition". Acta Physiol Hung. 2005;92(2):121-37.

31. Safarinejad MR, Azma K, Kolahi AA. The effects of intensive, long-term treadmill running on reproductive hormones, hypothalamus-pituitary-testis axis, and semen quality: a randomized controlled study. J Endocrinol. 2009; 200(3):259-71.

32. Wade CE, Stanford KI, Stein TP, Greenleaf JE. Intensive exercise training suppresses testosterone during bed rest. J Appl Physiol (1985). 2005;99(1):59-63.

33. Anderson T, Lane AR, Hackney AC. Cortisol and testosterone dynamics following exhaustive endurance exercise. Eur J Appl Physiol. 2016;116(8):1503-9.

34. Marinelli M, Roi GS, Giacometti M, Bonini P, Banfi G. Cortisol, testosterone, and free testosterone in athletes performing a marathon at 4,000 $\mathrm{m}$ altitude. Horm Res. 1994;41(5-6):225-9.
35. Hoogeveen AR, Zonderland ML. Relationships between testosterone, cortisol and performance in professional cyclists. Int J Sports Med. 1996; 17(6):423-8

36. Di Luigi L, Sgro P, Fierro V, Bianchini S, Battistini G, Magini V, Jannini EA, Lenzi A. Prevalence of undiagnosed testosterone deficiency in aging athletes: does exercise training influence the symptoms of male hypogonadism? J Sex Med. 2010;7(7):2591-601.

37. Zitzmann M. Effects of testosterone replacement and its pharmacogenetics on physical performance and metabolism. Asian J Androl. 2008;10(3):364-72.

38. Booth FW, Roberts CK, Laye MJ. Lack of exercise is a major cause of chronic diseases. Compr Physiol. 2012;2(2):1143-211.

39. Sgro P, Di Luigi L. Sport and male sexuality. J Endocrinol Invest. 2017;40(9): 911-23.

40. La Vignera S, Condorelli R, Vicari E, D'Agata R, Calogero AE. Physical activity and erectile dysfunction in middle-aged men. J Androl. 2012:33(2):154-61.

41. Agostini LC, Netto JM, Miranda MV Jr, Figueiredo AA. Erectile dysfunction association with physical activity level and physical fitness in men aged 4075 years. Int J Impot Res. 2011;23(3):115-21.

42. Maiorino Ml, Bellastella G, Esposito K. Lifestyle modifications and erectile dysfunction: what can be expected? Asian J Androl. 2015;17(1):5-10

43. Shamloul R, Ghanem H. Erectile dysfunction. Lancet (London, England). 2013;381(9861):153-65

44. Richter B, Niessner A, Penka M, Grdic M, Steiner S, Strasser B, Ziegler S, Zorn $G$, Maurer $G$, Simeon-Rudolf $V$, et al. Endurance training reduces circulating asymmetric dimethylarginine and myeloperoxidase levels in persons at risk of coronary events. Thromb Haemost. 2005;94(6):1306-11.

45. Ribeiro F, Alves AJ, Duarte JA, Oliveira J. Is exercise training an effective therapy targeting endothelial dysfunction and vascular wall inflammation? Int J Cardiol. 2010;141(3):214-21.

46. Guay AT. ED2: erectile dysfunction = endothelial dysfunction. Endocrinol Metab Clin N Am. 2007;36(2):453-63.

47. Silva AB, Sousa N, Azevedo LF, Martins C. Physical activity and exercise for erectile dysfunction: systematic review and meta-analysis. Br J Sports Med. 2017:51(19):1419-24.

48. Lamina S, Agbanusi E, Nwacha RC. Effects of aerobic exercise in the management of erectile dysfunction: a meta analysis study on randomized controlled trials. Ethiop J Health Sci. 2011;21(3):195-201.

49. Joy E, De Souza MJ, Nattiv A, Misra M, Williams NI, Mallinson RJ, Gibbs JC, Olmsted M, Goolsby M, Matheson G, et al. 2014 female athlete triad coalition consensus statement on treatment and return to play of the female athlete triad. Curr Sports Med Rep. 2014;13(4):219-32.

50. Tenforde AS, Barrack MT, Nattiv A, Fredericson M. Parallels with the Female Athlete Triad in Male Athletes. Sports Med (Auckland, NZ). 2016 46(2):171-82

51. Sansone A, Romanelli F, Gianfrilli D, Lenzi A. Endocrine evaluation of erectile dysfunction. Endocrine. 2014;46(3):423-30

52. Sansone A, Romanelli F, Jannini EA, Lenzi A. Hormonal correlations of premature ejaculation. Endocrine. 2015;49(2):333-8.

53. Cunningham GR, Stephens-Shields AJ, Rosen RC, Wang C, Ellenberg SS, Matsumoto AM, Bhasin S, Molitch ME, Farrar JT, Cella D, et al. Association of sex hormones with sexual function, vitality, and physical function of symptomatic older men with low testosterone levels at baseline in the testosterone trials. J Clin Endocrinol Metab. 2015:100(3):1146-55.

54. Corona G, Isidori AM, Buvat J, Aversa A, Rastrelli G, Hackett G, Rochira V, Sforza A, Lenzi A, Mannucci E, et al. Testosterone supplementation and sexual function: a meta-analysis study. J Sex Med. 2014;11(6):1577-92.

55. Ventus D, Jern P. Lifestyle factors and premature ejaculation: are physical exercise, alcohol consumption, and body mass index associated with premature ejaculation and comorbid erectile problems? J Sex Med. 2016;13(10):1482-7.

56. Minguez-Alarcon L, Chavarro JE, Mendiola J, Gaskins AJ, Torres-Cantero AM. Physical activity is not related to semen quality in young healthy men. Fertil Steril. 2014;102(4):1103-9.

57. Vaamonde D, Da Silva-Grigoletto ME, Garcia-Manso JM, Vaamonde-Lemos R Swanson RJ, Oehninger SC. Response of semen parameters to three training modalities. Fertil Steril. 2009;92(6):1941-6.

58. Vaamonde D, Da Silva-Grigoletto ME, Garcia-Manso JM, Barrera N, Vaamonde-Lemos R. Physically active men show better semen parameters and hormone values than sedentary men. Eur J Appl Physiol. 2012;112(9):3267-73.

59. Hajizadeh Maleki B, Tartibian B, Chehrazi M. The effects of three different exercise modalities on markers of male reproduction in healthy subjects: a 
randomized controlled trial. Reproduction (Cambridge, England). 2017; 153(2):157-74.

60. Hajizadeh Maleki B, Tartibian B, Eghbali M, Asri-Rezaei S. Comparison of seminal oxidants and antioxidants in subjects with different levels of physical fitness. Andrology. 2013;1(4):607-14.

61. Hajizadeh Maleki B, Tartibian B. Moderate aerobic exercise training for improving reproductive function in infertile patients: a randomized controlled trial. Cytokine. 2017;92:55-67.

62. Rosety MA, Diaz AJ, Rosety JM, Pery MT, Brenes-Martin F, Bernardi M, Garcia N, Rosety-Rodriguez M, Ordonez FJ, Rosety I. Exercise improved semen quality and reproductive hormone levels in sedentary obese adults. Nutr Hosp. 2017;34(3):603-7.

63. Maleki BH, Tartibian B. High-intensity exercise training for improving reproductive function in infertile patients: a randomized controlled trial. J Obstet Gynaecol Can. 2017;39(7):545-58.

64. Maleki BH, Tartibian B, Vaamonde D. The effects of 16 weeks of intensive cycling training on seminal oxidants and antioxidants in male road cyclists. Clin J Sport Med. 2014;24(4):302-7.

65. De Souza MJ, Miller BE. The effect of endurance training on reproductive function in male runners. A 'volume threshold' hypothesis. Sports Med (Auckland, NZ). 1997:23(6):357-74

66. Vaamonde D, Da Silva-Grigoletto ME, Fernandez JM, Algar-Santacruz C, García-Manso JM. Findings on sperm alterations and DNA fragmentation, nutritional, hormonal and antioxidant status in an elite triathlete. Case report. Rev Andal Med Deporte. 2014;7:143-8.

67. Manna I, Jana K, Samanta PK. Effect of different intensities of swimming exercise on testicular oxidative stress and reproductive dysfunction in mature male albino Wistar rats. Indian J Exp Biol. 2004;42(8):816-22.

68. Manna I, Jana K, Samanta PK. Effect of intensive exercise-induced testicular gametogenic and steroidogenic disorders in mature male Wistar strain rats: a correlative approach to oxidative stress. Acta Physiol Scand. 2003;178(1):33-40.

69. Wise LA, Cramer DW, Hornstein MD, Ashby RK, Missmer SA. Physical activity and semen quality among men attending an infertility clinic. Fertil Steril. 2011;95(3):1025-30.

70. Rafiee B, Morowvat MH, Rahimi-Ghalati N. Comparing the effectiveness of dietary vitamin $\mathrm{C}$ and exercise interventions on fertility parameters in Normal obese men. Urol J. 2016;13(2):2635-9.

71. Gaskins AJ, Afeiche MC, Hauser R, Williams PL, Gillman MW, Tanrikut C, Petrozza JC, Chavarro JE. Paternal physical and sedentary activities in relation to semen quality and reproductive outcomes among couples from a fertility center. Human Reprod (Oxford, England). 2014;29(11):2575-82.

72. Schumacher YO, Mueller P. The 4000-m team pursuit cycling world record: theoretical and practical aspects. Med Sci Sports Exerc. 2002;34(6):1029-36.

73. Tonnessen E, Sylta O, Haugen TA, Hem E, Svendsen IS, Seiler S. The road to gold: training and peaking characteristics in the year prior to a gold medal endurance performance. PLoS One. 2014;9(7):e101796.

74. Durairajanayagam D, Agarwal A, Ong C. Causes, effects and molecular mechanisms of testicular heat stress. Reprod BioMed Online. 2015;30(1):14-27.

75. Bedford JM. Human spermatozoa and temperature: the elephant in the room. Biol Reprod. 2015;93(4):97.

76. Jung A, Leonhardt F, Schill WB, Schuppe HC. Influence of the type of undertrousers and physical activity on scrotal temperature. Human Reprod (Oxford, England). 2005;20(4):1022-7.

77. Jung A, Strauss P, Lindner HJ, Schuppe HC. Influence of moderate cycling on scrotal temperature. Int J Androl. 2008;31(4):403-7.

78. Southorn T. Great balls of fire and the vicious cycle: a study of the effects of cycling on male fertility. J Fam Plann Reprod Health Care. 2002;28(4):211-3.

79. Pelliccione F, Verratti V, D'Angeli A, Micillo A, Doria C, Pezzella A, lacutone G, Francavilla F, Di Giulio C, Francavilla S. Physical exercise at high altitude is associated with a testicular dysfunction leading to reduced sperm concentration but healthy sperm quality. Fertil Steril. 2011;96(1):28-33.

80. Aitken RJ, Buckingham D, Richardson D, Gardiner JC, Irvine DS. Impact of a deep saturation dive on semen quality. Int J Androl. 2000;23(2):116-20.

81. Leibovitch I, Mor Y. The vicious cycling: bicycling related urogenital disorders. Eur Urol. 2005:47(3):277-86 discussion 286-277.

82. Kelly DF, Chaloner C, Evans D, Mathews A, Cohan P, Wang C, Swerdloff R, Sim MS, Lee J, Wright MJ, et al. Prevalence of pituitary hormone dysfunction, metabolic syndrome, and impaired quality of life in retired professional football players: a prospective study. J Neurotrauma. 2014; 31(13):1161-71.
83. Tanriverdi F, Unluhizarci K, Coksevim B, Selcuklu A, Casanueva FF, Kelestimur F. Kickboxing sport as a new cause of traumatic brain injury-mediated hypopituitarism. Clin Endocrinol. 2007;66(3):360-6.

84. Tanriverdi F, Kelestimur F. Neuroendocrine disturbances after brain damage: an important and often undiagnosed disorder. J Clin Med. 2015;4(5):847-57.

85. Dubourg J, Messerer M. Sports-related chronic repetitive head trauma as a cause of pituitary dysfunction. Neurosurg Focus. 2011;31(5):E2.

86. Nemes O, Kovacs N, Czeiter E, Kenyeres P, Tarjanyi Z, Bajnok L, Buki A, Doczi T, Mezosi E. Predictors of post-traumatic pituitary failure during long-term follow-up. Hormones (Athens, Greece). 2015;14(3):383-91.

87. Tanriverdi F, De Bellis A, Ulutabanca H, Bizzarro A, Sinisi AA, Bellastella G Amoresano Paglionico V, Dalla Mora L, Selcuklu A, Unluhizarci K, et al. A five year prospective investigation of anterior pituitary function after traumatic brain injury: is hypopituitarism long-term after head trauma associated with autoimmunity? J Neurotrauma. 2013;30(16):1426-33.

88. Marceau L, Kleinman K, Goldstein I, McKinlay J. Does bicycling contribute to the risk of erectile dysfunction? Results from the Massachusetts male aging study (MMAS). Int J Impot Res. 2001;13(5):298-302.

89. Rigano E, Santoro G, Impellizzeri P, Antonuccio P, Fugazzotto D, Bitto L, Romeo $C$. Varicocele and sport in the adolescent age. Preliminary report on the effects of physical training. J Endocrinol Invest. 2004;27(2):130-2

90. Di Luigi L, Gentile V, Pigozzi F, Parisi A, Giannetti D, Romanelli F. Physical activity as a possible aggravating factor for athletes with varicocele: impact on the semen profile. Human Reprod (Oxford, England). 2001; 16(6):1180-4.

91. Zampieri N, Dall'Agnola A. Subclinical varicocele and sports: a longitudinal study. Urology. 2011;77(5):1199-202.

92. Chan CW, Eng JJ, Tator CH, Krassioukov A. Spinal cord injury research evidence T: epidemiology of sport-related spinal cord injuries: a systematic review. J Spinal Cord Med. 2016;39(3):255-64.

93. Bailes JE, Petschauer M, Guskiewicz KM, Marano G. Management of cervical spine injuries in athletes. J Athl Train. 2007:42(1):126-34.

94. Ibrahim E, Lynne CM, Brackett NL. Male fertility following spinal cord injury: an update. Andrology. 2016;4(1):13-26.

95. Fode M, Krogh-Jespersen S, Brackett NL, Ohl DA, Lynne CM, Sonksen J. Male sexual dysfunction and infertility associated with neurological disorders. Asian J Androl. 2012;14(1):61-8.

96. Trofimenko V, Hotaling JM. Fertility treatment in spinal cord injury and other neurologic disease. Transl Androl Urol. 2016;5(1):102-16.

97. Brant WO, Myers JB, Carrell DT, Smith JF. Male athletic activities and their effects on semen and hormonal parameters. Phys Sportsmed. 2010;38(3):114-20.

98. Sandella B, Hartmann B, Berkson D, Hong E. Testicular conditions in athletes: torsion, tumors, and epididymitis. Curr Sports Med Rep. 2012;11(2):92-5.

99. Hunter SR, Lishnak TS, Powers AM, Lisle DK. Male genital trauma in sports. Clin Sports Med. 2013;32(2):247-54

100. Piacentino D, Kotzalidis GD, Del Casale A, Aromatario MR, Pomara C, Girardi P, Sani G. Anabolic-androgenic steroid use and psychopathology in athletes. A systematic review. Curr Neuropharmacol. 2015;13(1):101-21.

101. Di Luigi L, Romanelli F, Lenzi A. Androgenic-anabolic steroids abuse in males. J Endocrinol Invest. 2005;28(3 Suppl):81-4.

102. Di Luigi L. Supplements and the endocrine system in athletes. Clin Sports Med. 2008;27(1):131-51 ix.

103. Di Luigi L, Rossi C, Sgro P, Fierro V, Romanelli F, Baldari C, Guidetti L. Do non-steroidal anti-inflammatory drugs influence the steroid hormone milieu in male athletes? Int J Sports Med. 2007:28(10):809-14.

104. Nieschlag E, Vorona E. Mechanisms in Endocrinology: medical consequences of doping with anabolic androgenic steroids: effects on reproductive functions. Eur J Endocrinol. 2015;173(2):R47-58.

105. Rahnema CD, Lipshultz LI, Crosnoe LE, Kovac JR, Kim ED. Anabolic steroidinduced hypogonadism: diagnosis and treatment. Fertil Steril. 2014;101(5):1271-9.

106. Schilling K, Toth B, Rosner S, Strowitzki T, Wischmann T. Prevalence of behaviour-related fertility disorders in a clinical sample: results of a pilot study. Arch Gynecol Obstet. 2012;286(5):1307-14.

107. Shokri S, Hemadi M, Bayat G, Bahmanzadeh M, Jafari-Anarkooli I, Mashkani $B$. Combination of running exercise and high dose of anabolic androgenic steroid, nandrolone decanoate, increases protamine deficiency and DNA damage in rat spermatozoa. Andrologia. 2014;46(2):184-90.

108. Shokri S, Aitken RJ, Abdolvahhabi M, Abolhasani F, Ghasemi FM, Kashani I, Ejtemaeimehr S, Ahmadian S, Minaei B, Naraghi MA, et al. Exercise and supraphysiological dose of nandrolone decanoate increase apoptosis in spermatogenic cells. Basic Clin Pharmacol Toxicol. 2010;106(4):324-30. 
109. de Souza GL, Hallak J. Anabolic steroids and male infertility: a comprehensive review. BJU Int. 2011;108(11):1860-5.

110. Kim ED, Crosnoe L, Bar-Chama N, Khera M, Lipshultz LI. The treatment of hypogonadism in men of reproductive age. Fertil Steril. 2013;99(3):718-24.

111. Turek PJ, Williams RH, Gilbaugh JH 3rd, Lipshultz LI. The reversibility of anabolic steroid-induced azoospermia. J Urol. 1995;153(5):1628-30.

112. Menon DK. Successful treatment of anabolic steroid-induced azoospermia with human chorionic gonadotropin and human menopausal gonadotropin. Fertil Steril. 2003;79(Suppl 3):1659-61.

113. Skarberg K, Nyberg F, Engstrom I. Multisubstance use as a feature of addiction to anabolic-androgenic steroids. Eur Addict Res. 2009;15(2):99-106.

114. Gazvani MR, Buckett W, Luckas MJ, Aird IA, Hipkin LJ, Lewis-Jones DI. Conservative management of azoospermia following steroid abuse. Human Reprod (Oxford, England). 1997;12(8):1706-8.

115. Rogol AD. Can anabolic steroids or human growth hormone affect the growth and maturation of adolescent athletes? Pediatr Exerc Sci. 2014;26(4):423-7.

116. Pope HG Jr, Wood Rl, Rogol A, Nyberg F, Bowers L, Bhasin S. Adverse health consequences of performance-enhancing drugs: an Endocrine Society scientific statement. Endocr Rev. 2014;35(3):341-75.

117. Wenker EP, Dupree JM, Langille GM, Kovac J, Ramasamy R, Lamb D, Mills JN, Lipshultz LI. The use of HCG-based combination therapy for recovery of spermatogenesis after testosterone use. J Sex Med. 2015;12(6):1334-7.

118. Karila T, Hovatta O, Seppala T. Concomitant abuse of anabolic androgenic steroids and human chorionic gonadotrophin impairs spermatogenesis in power athletes. Int J Sports Med. 2004;25(4):257-63.

119. Di Luigi L, Baldari C, Sgro P, Emerenziani GP, Gallotta MC, Bianchini S, Romanelli F, Pigozzi F, Lenzi A, Guidetti L. The type 5 phosphodiesterase inhibitor tadalafil influences salivary cortisol, testosterone, and dehydroepiandrosterone sulphate responses to maximal exercise in healthy men. J Clin Endocrinol Metab. 2008;93(9):3510-4.

120. Di Luigi L, Baldari C, Pigozzi F, Emerenziani GP, Gallotta MC, lellamo F, Ciminelli E, Sgro P, Romanelli F, Lenzi A, et al. The long-acting phosphodiesterase inhibitor tadalafil does not influence athletes' VO2max, aerobic, and anaerobic thresholds in normoxia. Int J Sports Med. 2008;29(2):110-5.

121. Ceci R, Duranti G, Sgro P, Sansone M, Guidetti L, Baldari C, Sabatini S, Di Luigi $L$. Effects of tadalafil administration on plasma markers of exerciseinduced muscle damage, IL6 and antioxidant status capacity. Eur J Appl Physiol. 2015;115(3):531-9.

122. Chrysant SG. Antihypertensive therapy causes erectile dysfunction. Curr Opin Cardiol. 2015;30(4):383-90.

123. Drobnis EZ, Nangia AK. Cardiovascular/pulmonary medications and male reproduction. Adv Exp Med Biol. 2017;1034:103-30.

124. Schwarz ER, Rodriguez J. Sex and the heart. Int J Impot Res. 2005; 17(Suppl 1):S4-6.

125. Cadwallader AB, de la Torre $X$, Tieri A, Botre F. The abuse of diuretics as performance-enhancing drugs and masking agents in sport doping: pharmacology, toxicology and analysis. Br J Pharmacol. 2010;161(1):1-16.

126. Mayr FB, Domanovits H, Laggner AN. Hypokalemic paralysis in a professional bodybuilder. Am J Emerg Med. 2012;30(7):1324 e1325-1328.

127. Lee TW, Bae E, Hwang K, Chang HN, Park HJ, Jeon DH, Cho HS, Chang SH, Park DJ. Severe hypokalemic paralysis and rhabdomyolysis occurring after binge eating in a young bodybuilder: case report. Medicine (Baltimore). 2017;96(40):e8251.

128. Trinh KV, Kim J, Ritsma A. Effect of pseudoephedrine in sport: a systematic review. BMJ Open Sport Exerc Med. 2015;1(1):e000066.

129. Momaya A, Fawal M, Estes R. Performance-enhancing substances in sports: a review of the literature. Sports medicine (Auckland, NZ). 2015;45(4):517-31.

130. Thevis M, Sigmund G, Geyer H, Schanzer W. Stimulants and doping in sport. Endocrinol Metab Clin N Am. 2010;39(1):89-105 ix.

131. Chou NH, Huang YJ, Jiann BP. The impact of illicit use of amphetamine on male sexual functions. J Sex Med. 2015:12(8):1694-702.

132. Fronczak CM, Kim ED, Barqawi $A B$. The insults of illicit drug use on male fertility. J Androl. 2012;33(4):515-28.

133. Lombardo F, Sansone A, Romanelli F, Paoli D, Gandini L, Lenzi A. The role of antioxidant therapy in the treatment of male infertility: an overview. Asian J Androl. 2011;13(5):690-7.

134. Cederroth CR, Auger J, Zimmermann C, Eustache F, Nef S. Soy, phytooestrogens and male reproductive function: a review. Int J Androl. 2010; 33(2):304-16.
135. Beaton LK, McVeigh BL, Dillingham BL, Lampe JW, Duncan AM. Soy protein isolates of varying isoflavone content do not adversely affect semen quality in healthy young men. Fertil Steril. 2010;94(5):1717-22.

136. Butts J, Jacobs B, Silvis M. Creatine use in sports. Sports Health. 2018; 10(1):31-4.

137. Lucia A, Diaz B, Hoyos J, Fernandez C, Villa G, Bandres F, Chicharro JL. Hormone levels of world class cyclists during the tour of Spain stage race. Br J Sports Med. 2001;35(6):424-30.

138. Fernandez-Garcia B, Lucia A, Hoyos J, Chicharro JL, Rodriguez-Alonso M, Bandres $F$, Terrados $N$. The response of sexual and stress hormones of male pro-cyclists during continuous intense competition. Int J Sports Med. 2002; 23(8):555-60.

139. Maimoun L, Lumbroso S, Manetta J, Paris F, Leroux JL, Sultan C. Testosterone is significantly reduced in endurance athletes without impact on bone mineral density. Horm Res. 2003;59(6):285-92.

140. Grandys M, Majerczak J, Duda K, Zapart-Bukowska J, Kulpa J, Zoladz JA. Endurance training of moderate intensity increases testosterone concentration in young, healthy men. Int J Sports Med. 2009;30(7):489-95.

141. Wheeler GD, Singh M, Pierce WD, Epling WF, Cumming DC. Endurance training decreases serum testosterone levels in men without change in luteinizing hormone pulsatile release. J Clin Endocrinol Metab. 1991;72(2): 422-5.

142. Houmard JA, Costill DL, Mitchell JB, Park SH, Fink WJ, Burns JM. Testosterone, cortisol, and creatine kinase levels in male distance runners during reduced training. Int J Sports Med. 1990;11(1):41-5.

143. Garber CE, Blissmer B, Deschenes MR, Franklin BA, Lamonte MJ, Lee IM, Nieman DC, Swain DP. American College of Sports Medicine position stand. Quantity and quality of exercise for developing and maintaining cardiorespiratory, musculoskeletal, and neuromotor fitness in apparently healthy adults: guidance for prescribing exercise. Med Sci Sports Exerc. 2011;43(7):1334-59.

144. Kumagai H, Zempo-Miyaki A, Yoshikawa T, Tsujimoto T, Tanaka K, Maeda S Increased physical activity has a greater effect than reduced energy intake on lifestyle modification-induced increases in testosterone. J Clin Biochem Nutr. 2016;58(1):84-9.

145. Swain DP. Moderate or vigorous intensity exercise: which is better for improving aerobic fitness? Prev Cardiol. 2005:8(1):55-8.

146. Swain DP, Abernathy KS, Smith CS, Lee SJ, Bunn SA. Target heart rates for the development of cardiorespiratory fitness. Med Sci Sports Exerc. 1994; 26(1):112-6.

147. Lounana J, Campion F, Noakes TD, Medelli J. Relationship between $\% H R m a x, \% H R$ reserve, \%VO2max, and \%VO2 reserve in elite cyclists. Med Sci Sports Exerc. 2007;39(2):350-7.

148. Stoggl TL, Sperlich B. The training intensity distribution among well-trained and elite endurance athletes. Front Physiol. 2015;6:295

149. Seiler $\mathrm{S}$. What is best practice for training intensity and duration distribution in endurance athletes? Int J Sports Physiol Perform. 2010;5(3):276-91.

Ready to submit your research? Choose BMC and benefit from:

- fast, convenient online submission

- thorough peer review by experienced researchers in your field

- rapid publication on acceptance

- support for research data, including large and complex data types

- gold Open Access which fosters wider collaboration and increased citations

- maximum visibility for your research: over $100 \mathrm{M}$ website views per year

At $\mathrm{BMC}$, research is always in progress.

Learn more biomedcentral.com/submissions 